\title{
Family Adjustment of Working Women In Relation To Type of Occupation and Area of Residence
}

\author{
Dr. Jayshree D. Gajjar ${ }^{1}$
}

\section{ABSTRACT}

The main purpose of the present research was to study and compare various areas of family adjustment with regards to working women of different occupation and area of residence. The sample consisted of 180 working women (30 urban women teachers, 30 urban women doctor, 30 urban women bank employee, 30 rural women teachers, 30 rural women doctor and 30 rural women bank employee). Family adjustment inventory of working women by Vishwa Vijay Singh was used for data collection. To analyzed the obtained data two way analysis of variance was used. The results indicate that significant difference was found between urban and rural working women with regards to self adjustment, family adjustment, adjustment with children, and adjustment with husband. Significant difference was also found among women teacher, women doctor and woman bank employees with regards to adjustment with self , adjustment with family and adjustment with relatives. Significant interaction effect was found between area of residence and type of occupation with regards to adjustment with family, adjustment with children, adjustment with husband and adjustment with relatives.

Keywords: Family Adjustment, Occupation, Women

The working women, is not a new addition to the Indian scene. Women in the labor field have been working since long for wages $n$ factories as menial servants or as unskilled laborers and on construction sites. It is only the women of middle or upper classes who were confined to homes and taking up jobs was considered dilatory for them. Various social - economic and politico legal factors have brought about a newly emerging middle class of working women in India. With the passage of time, society's attitude towards them also changed. No longer does the smug middle class look down upon women doing a job, whether it is express herself or to utilize her talents or be economically independent, at least on extent or just to earn pin-money.

\footnotetext{
${ }^{1}$ Lecturer, Department of Psychology, Shree P. H. G. Muni. Arts and Science College, Kalol (North Gujarat

(C) 2015 I J Gajjar; licensee IJIP. This is an Open Access Research distributed under the terms of the Creative Commons Attribution License (http://creativecommons.org/licenses/by/2.0), which permits unrestricted use, distribution, and reproduction in any Medium, provided the original work is properly cited.
} 
In present economic hardship and crisis wife's participation for family financing Is also required. The attitude of society towards married women talking up jobs has also changed. The reason of social change is that many married women work without reproach is because everyone understands the economic problems of middle class and that a wife's to the family standard of living and marital happiness and satisfaction depend upon work and carrier of the marital partner. Marriage is a social cultural system providing satisfaction for love, affection, intimacy, relatedness, affiliation, emotional sustenance, financial - social service. The personality, selfconcept, personal and social attitude, cultural values, socio-economic status, educational level, work status, family type, natively, occupation etc. influence. There are individual and group differences in the family adjustment, marital satisfaction and mental health.

Harrison and Minor' (1978) found that being away from house and children is a constant source of tension for working mothers as they to weight the benefits of working women against their concerns for the well being of their children, the absence of adequate childcare facilities for the Indian working mother to resolve this conflict.

Gupta and Ganguli (1982) found that there are other factors operating within the family that acted in interaction with the husbands approval to determine that women adjustment to her multiple roles and that in one joint family these factors hindered her adjustment where as in the nuclear family they facilitated it.

Rivere et. al. (1997) explored the relative effects of employment and family responsibility on the perceived health status of women. The results suggest that is a need for a development of public politics that seek to increase labor force participation rate since any expansion has the potential to have positive impact on their health status.

Sahu and misra (1995) concluded that working women teachers feel more stress because of their dual responsibilities and more concerned with family as expected from females.

Rivera et al. (1997) found that annual employment house, occupation and family responsibilities, such as childcare and weekly housewife significantly affect self-reported health status of employed women.

Makovaska (1995) conclude that family greater demands on women take a higher told on women's adjustment in the dual carrier as compared to males.

\section{OBJECTIVES}

1. To study and compare different areas of adjustment such as self adjustment, family adjustment with children, adjustment with husband, and adjustment with relatives between urban and rural working women. 
2. To study and compare different areas of adjustment such as self adjustment, family adjustment, adjustment with children, adjustment with husband, and adjustment with relatives among women teacher, women doctor and woman bank employees.

3. To study interaction effect between area of residence and occupation of working women with regards to different areas of adjustment such as self adjustment, family adjustment, adjustment with children, adjustment with husband, and adjustment with relatives.

\section{HYPOTHESES}

1. There will be no significant difference between urban and rural working women with regards to different areas of adjustment such as self adjustment, family adjustment, and adjustment with children, adjustment with husband, and adjustment with relatives.

2. There will be no significant difference among women teacher, women doctor and woman bank employees with regards to different areas of adjustment such as self adjustment, family adjustment, adjustment with children, adjustment with husband, and adjustment with relatives.

3. There will be no significant interaction effect between area of residence and occupation of working women with regards to different areas of adjustment such as self adjustment, family adjustment, adjustment with children, adjustment with husband, and adjustment with relatives.

\section{SAMPLE}

In present research 180 working women (30 urban women teachers, 30 urban women doctor, 30 urban women bank employee, 30 rural women teachers, 30 rural women doctor and 30 rural women bank employee) were randomly selected from different areas of Ahmadabad city.

\section{VARIABLES}

In present research area of residence and occupation of working women were considered as independent variable and scores of various adjustment of working women was consider as dependent variable.

\section{TOOLS}

In present research Family adjustment inventory of working women by Vishwa Vijay Singh was used for data collection. 


\section{PROCEDURE}

Family adjustment inventory of working women was administered in small manageable group of participants, before this rapport was establish with each participants. After completion the data collection responses of each participants of inventory was scored by the scoring key of scale.

\section{STATISTICAL ANALYSIS}

To analyze the obtained data 2x3 ANOVA was used.

Summary results of ANOVA on different areas of adjustment of various groups of women.

\begin{tabular}{|c|c|c|c|c|c|c|}
\hline \multirow{3}{*}{ Source of variation } & \multirow{3}{*}{$\mathrm{df}$} & \multicolumn{5}{|c|}{ F value } \\
\hline & & \multicolumn{5}{|c|}{ Different areas of adjustment } \\
\hline & & $\begin{array}{l}\text { Adjustment } \\
\text { with self }\end{array}$ & $\begin{array}{l}\text { Adjustment } \\
\text { with family }\end{array}$ & $\begin{array}{l}\text { Adjustment } \\
\text { with children }\end{array}$ & $\begin{array}{c}\text { Adjustment } \\
\text { with husband }\end{array}$ & $\begin{array}{l}\text { Adjustment } \\
\text { with relatives }\end{array}$ \\
\hline Area of residence & 1 & $4.44^{*}$ & $4.56^{*}$ & $3.94^{*}$ & $5.46^{*}$ & 0.69 \\
\hline Occupation & 2 & $5.98^{\text {* }}$ & $4.83^{* \star}$ & 0.27 & 1.34 & $4.28^{* \pi}$ \\
\hline $\begin{array}{l}\text { Area of residence } \\
\text { and occupation }\end{array}$ & 2 & 1.06 & $3.50^{*}$ & $4.86^{*}$ & $4.18^{*}$ & $5.76^{* \star}$ \\
\hline Error & 174 & & & & & \\
\hline
\end{tabular}

Above table shows the summery results of ANOVA of various areas of adjustment of various group of women. F ratio for Area of residence on adjustment with self (Ass) is 4.44 which is significant at .05 level. It means significant difference exists between urban and rural working women on adjustment with self. By the same point of view mean scores of urban working women on adjustment with self is 27.34 and mean scores of rural working women on adjustment with self is 28.92. It is clearly said that significant difference exists between urban and rural working women on adjustment with self.

F ratio for Occupation (Bss) on adjustment with self is 5.98 which is significant at .01 level. It means significant difference is existed among women teachers, women doctors and woman bank employees on adjustment with self. By the same point of view mean scores of women teachers on adjustment with self is 28.03 and mean scores of women doctors on adjustment with self is 26.60 and mean scores of women bank employees on adjustment with self is 29.77. It is clearly said that significant difference exist among women teachers, women doctors and woman bank employees on adjustment with self. 
F ratio for Area of residence and occupation $(\mathrm{AxB})$ on adjustment with self is 1.06 which is not significant. It means significant interaction effect does not exist between Area of residence and occupation on different areas of adjustment such as self adjustment. By the same point of view mean scores of urban women teachers on adjustment with self is 27.20, mean scores of urban women doctors on adjustment with self is 25.17, mean scores of urban women bank employees on adjustment with self is 29.67, mean scores of rural women teachers on adjustment with self is 28.87, mean scores of rural women doctors on adjustment with self is 28.03 , mean scores of rural women bank employees on adjustment with self is 29.87 .

F ratio for Area of residence (Ass) on adjustment with family is 4.56 which is significant at 05 level. It means significant difference exists between urban and rural working women on adjustment with family. By the same point of view mean scores of urban working women on adjustment with family is 27.34 and mean scores of rural working women on adjustment with family is 28.92. It is clearly said that significant difference exist between urban and rural working women on adjustment with family.

F ratio for Occupation (Bss) on adjustment with family is 4.83 which is significant at .01 level. It means significant difference exists among women teachers, women doctors and woman bank employees on adjustment with family. By the same point of view mean scores of women teachers on adjustment with family is 33.38 and mean scores of women doctors on adjustment with family is 33.35 and mean scores of women bank employees on adjustment with family is 35.98. It is clearly said that significant difference exist among women teachers, women doctors and woman bank employees on adjustment with family.

F ratio for Area of residence and occupation $(\mathrm{AxB})$ on adjustment with family is 3.50 which is significant at .05 leve. It means significant interaction effect exists between Area of residence and occupation on family adjustment. By the same point of view mean scores of urban women teachers on adjustment with family is 31.27 , mean scores of urban women doctors on adjustment with family is 33.90, mean scores of urban women bank employees on adjustment with family is 35.30, mean scores of rural women teachers on adjustment with family is 35.50, mean scores of rural women doctors on adjustment with family is 33.20, mean scores of rural women bank employees on adjustment with family is 36.67. It is clearly said that significant interaction effect exists between area of residence and occupation of working women on family adjustment.

F ratio for Area of residence (Ass) is on adjustment with children 3.94 which is significant at 05 level. It means significant difference is existed between urban and rural working women on adjustment with children. By the same point of view mean scores of urban working women on adjustment with children is 28.09 and mean scores of rural working women on adjustment with children is 29.68. It is clearly said that significant difference exists between urban and rural working women on adjustment with children. 
F ratio for Occupation (Bss) on adjustment with children i s 0.27 which is not significant. It means significant difference does not exists among women teachers, women doctors and woman bank employees on adjustment with children. By the same point of view mean scores of women teachers on adjustment with children is 28.78 and mean scores of women doctors on adjustment with children is 28.63 and mean scores of women bank employees on adjustment with children is 29.30. It is clearly said that significant difference exist among women teachers, women doctors and woman bank employees on adjustment with children.

F ratio for Area of residence and occupation $(\mathrm{AxB})$ on adjustment with children is 4.86 which is significant at .05 level. It means significant interaction effect exists between Area of residence and occupation on different areas of adjustment with children. By the same point of view mean scores of urban women teachers on adjustment with children is 27.50, mean scores of urban women doctors on adjustment with children is 29.53, mean scores of urban women bank employees on adjustment with children is 27.23, mean scores of rural women teachers on adjustment with children is 29.93, mean scores of rural women doctors on adjustment with children is 27.73, mean scores of rural women bank employees on adjustment with children is 31.37. It is clearly said that significant interaction effect exists between area of residence and occupation of working women on adjustment with children.

F ratio for Area of residence (Ass) adjustment with husband is 5.46 which is significant at .05 level. It means significant difference is exists between urban and rural working women on adjustment with husband. By the same point of view mean scores of urban working women on adjustment with husband is 31.26 and mean scores of rural working women on adjustment with husband is 33.21. It is clearly said that significant difference exist between urban and rural working women on adjustment with husband.

F ratio for Occupation (Bss) on adjustment with husband is 1.34 which is not significant. It means significant difference does not exists among women teachers, women doctors and woman bank employees on adjustment with husband. By the same point of view mean scores of women teachers on adjustment with husband is 32.05 and mean scores of women doctors on adjustment with husband is 33.15 and mean scores of women bank employees on adjustment with husband is 31.50. It is clearly said that significant difference does not exists among women teachers, women doctors and woman bank employees on adjustment with husband.

F ratio for Area of residence and occupation $(\mathrm{AxB})$ on adjustment with husband is 4.18 which is significant at .05 leve. It means significant interaction effect exists between Area of residence and occupation on different areas of adjustment with husband. By the same point of view mean scores of urban women teachers on adjustment with husband is 29.53, mean scores of urban women doctors on adjustment with husband is 33.57, mean scores of urban women bank employees on adjustment with husband is 30.67, mean scores of rural women teachers on adjustment with husband is 34.57, mean scores of rural women doctors on adjustment with husband is 32.73, mean scores of rural women bank employees on adjustment with husband is 
32.33. It is clearly said that significant interaction effect exists between area of residence and occupation of working women on adjustment with husband.

F ratio for Area of residence (Ass) on adjustment with relatives is 0.69 which is not significant. It means significant difference does not exists between urban and rural working women on adjustment with relatives. By the same point of view mean scores of urban working women on adjustment with relatives is 17.74 and mean scores of rural working women on adjustment with relatives is 18.33. It is clearly said that significant difference does not exists between urban and rural working women on adjustment with relatives.

F ratio for Occupation (Bss) on adjustment with relatives is 4.28 which is significant at .01. It means significant difference exists among women teachers, women doctors and woman bank employees on adjustment with relatives. By the same point of view mean scores of women teachers on adjustment with relatives is 18.78 and mean scores of women doctors on adjustment with relatives is 18.77 and mean scores of women bank employees on adjustment with relatives is 16.57. It is clearly said that significant difference exists among women teachers, women doctors and woman bank employees on adjustment with relatives.

F ratio for Area of residence and occupation $(\mathrm{AxB})$ on adjustment with relatives is 5.76 which is significant at .01 level. It means significant interaction effect exists between Area of residence and occupation on different areas of adjustment with relatives adjustment. By the same point of view mean scores of urban women teachers on adjustment with relatives is 18.00 , mean scores of urban women doctors on adjustment with relatives is 20.13, mean scores of urban women bank employees on adjustment with relatives is 15.10, mean scores of rural women teachers on adjustment with relatives is 19.57, mean scores of rural women doctors on adjustment with relatives is 17.40 , mean scores of rural women bank employees on adjustment with relatives is 18.03. It is clearly said that significant significant interaction effect exists between area of residence and occupation of working women on adjustment with relatives.

\section{CONCLUSIONS}

1. Significant difference exists between urban and rural working women with regards to adjustment with self, adjustment with family, adjustment with children and adjustment with husband.

2. Significant difference exists among women teachers, women doctors and women bank employees with regards to adjustment with self, adjustment with family, and adjustment with relatives.

3. Significant interaction effect exists between area of residence and occupation with regards to adjustment with family, adjustment with children and adjustment with husband and adjustment with relatives. 


\section{REFERENCES}

Gupta G. R. Gangul H.C. (1982): Marriage work interaction : A study of Indian women, Indian journal of clinical psychology, 9:113-123.

Harrison A. 0. and Minor J.N. (1978): Inter role conflict, coping strategies and satisfaction among black working women. Journal of Marriage and The family, 40,4:799-806.

Konar, C. (1996) Problem of Urban working women in India. Competition Success Review, 131133.

Makowska, Z. (1995): Psychological characteristics of work and family as determinates of stress and well being of women: A preliminary study Int. J Occup Med Environ Health, 8 (3): 215-22.

Revera, R., Jorres, M.I. \& Carer, F.J. (1997) : Role burdens : The impact employment and family resposibilies on the health status of women.

Sahu, K. \& Mishra, N. (1995): Life stress and born out in female college teachers. Journal of the Indian Academy of Applied Psychology, 21 (2): 109-113.

Williams, R.B., Barefoot, J.C. \& Blumenthai, J.A. (1997): Psychosocial correlates of job strain in a sample of working women. Arch Gen Psychiatry, 54 (6): 543-8. 